\title{
Examining the Role of Cultural Landscape in Regional Development: Defining Criteria and Looking at Ephesus
}

\section{Gökçe Şimşek*}

\begin{abstract}
The link between regional development and cultural heritage has been at the center of theoretical discussions and practices in the field of preservation. Especially, varieties of practices and regional plans have been developed in different parts of the World such as Europe, Russia and South Africa in order to ensure regional development through cultural heritage. In this paper, it is accepted that a cultural landscape, as a sub-region of a particular region, is a relevant and meaningful unit that can contribute to the qualities of the region in terms of socio-cultural and economic aspects. In this context, the main goal of this paper is to develop a set of criteria that will act as a tool for identifying to which aspects of a cultural landscape has the potential to contribute regional development and to evaluate possible contributions of Ephesus and its cultural landscape to regional development. These criteria can be classified according to a framework implying a three-fold classification; improvements in the physical quality of the cultural landscape, economic dimension and socio-cultural dimension. As a result, this case indicates that cultural landscape has great potential to contribute to the social and
\end{abstract} Keywords: Cultural landscape, regional development, preservation, tourism, Ephesus

*Assoc. Prof. Dr. Adnan Menderes University Department of History of Art, Aydın, Turkey. E-mail: gokcesk@gmail.com 
economic development of a region. There is a great need to support community through tools such as awareness raising programmes, regional heritage planning, regional heritage institutions acting as regional agencies.

\section{INTRODUCTION}

The link between cultural landscape and regional development has been evolving in recent decades in parallel with the developments in theoretical and practical aspects. On the one hand, cultural landscapes are defined 'as combined works of nature and of man' (UNESCO, 1992) and representations of interactions between human society and settlement over time (CE, 2000). The explanation of types of landscapes has been put at the centre of research and discussions (for example, see Antrop, 2005; Vos and Meeks, 1999). Further, the changes in cultural landscape have been viewed as a threat due to their consequences such as loss of diversity, coherence and identity of the cultural landscape. However, these changes are essential parts of landscapes (Antrop, 2005). With the alteration of the conceptual level, the old notion stressing the importance of special valuable sites, especially natural ones, was replaced by a new notion to include all types of landscapes (Antrop, 2005). In addition, it is claimed that a 'landscape' is shaped by people's simultaneous, multiple identities as humans rather than élites (O'Keefe, 2016, p. 5). With the establishment of the European Landscape Convention, landscape is viewed as an expression of the diversity of people's shared cultural and natural heritage (EC, 2000). In order to define and implement landscape policies, the general public, regional authorities, and other interested parties, are put at the centre of decision-making processes. Moreover, emphasis is placed on the integration of the cultural landscape with all regional and town-planning policies and increasing the awareness of civil society, private organisations and public authorities regarding the role and value of landscapes (EC, 2000). As a result, cultural landscape as a sub-region draws its power from its natural and cultural heritage for regional development.

In parallel to these, the relation between heritage conservation and development has been deeply rooted since the ICOMOS conference held in Moscow and Suzdal, Russia (1978). At this conference, this relationship was mainly investigated through the consideration of historic monuments located in urban contexts. With the developments in world tourism, this link has been the subject of many arguments. On the one hand, it is argued that cultural values are compromised for commercial gain (Urry, 1990; ICOMOS, 1999), and the effects of undesirable overdevelopment and damage to cultural heritage as a result of tourism have been discussed. On the other hand, the values of cultural heritage for creating partnership opportunities and the mutual beneficial outcomes have been stressed (McKercher, Hoa and du Cros, 2005), and the importance of heritage tourism for reconnecting people to their cultural roots is emphasised (McCarthy, 1994). 
Although the contribution of cultural landscape to regional competitiveness can be evaluated in relation to several fieldssuch as creative industries and human resources-so far in the 2000s, heritage conservation has been directly related with regional development and tourism. The value of cultural landscape for increasing regional competitiveness is generally examined in relation with tourism destination competitiveness (Crouch \& Ritchie, 1999; Kozak \& Rimmington, 1999; Enright \& Newton, 2005). In the context of tourism, cultural tourism is viewed as one of the key drivers of European economic growth and development. The importance of preventing undesirable overdevelopment and related damage to cultural heritage through careful planning is emphasised (Europe Nostra, 2006).

Given the speed and the effects of the globalisation of societies, the relation between World Heritage and Sustainable Development was discussed on the 40 th anniversary of the World Heritage Convention in Kyoto (UNESCO, 2012). Especially for providing contributions of heritage conservation to the sustainable development, enhancing cooperation and coordination among all stakeholders and ensuring the involvement of local communities have been listed among its activities (UNESCO, 2012). In the Paris Declaration, heritage is viewed as the driver of development, and an attempt has been made to establish a link between heritage and regional development. At the theoretical level, the potentials of heritage for ensuring social cohesion, well-being, creativity and economic appeal are stressed. This link between heritage and regional development is explained in relation with three subthemes: (1) controlling and redistributing urban development, (2) revitalising towns and local economies and (3) preserving space (ICOMOS, 2011). At the practical level, the results of some projects carried out in Russia, Germany, England and Turkey indicate that cultural heritage has positive effects for regional development, such as growth of business, increased private investment, and increased cultural infrastructure (Menteș, 2006; Abankina, 2013). On the other hand, it has negative effects such as changes in social structures and increased expenses (Abankina, 2013). This is a challenge in terms of safeguarding the social structure and its values, and it is a complex issue to solve. At the same time, it is an opportunity in terms of economic development. The validity of the dichotomous relationship that characterises the interaction between cultural landscape and regional development needs to be examined. In this context, the main goal of this paper is to develop a set of criteria that will act as a tool for identifying to which aspects of a cultural landscape regional development has the potential to contribute. The cultural landscape of Ephesus will be the case study. It is accepted that a cultural landscape, as a subregion of a particular region, is a relevant and meaningful unit that can contribute to the qualities of a particular region. This acceptance requires an effort to analyse what regional development is. Therefore, the following subjects will be explained: (1) the link between the bottom-up regional development model and cultural landscape; (2) key indicators developed for understanding the role and contributions of 
cultural landscape in regional development, including tests of these indicators in the case of Ephesus; and (3) an evaluation and suggestions.

\section{BOTTOM-UP REGIONAL DEVELOPMENT MODEL AND CULTURAL LANDSCAPE}

In order to understand the link between cultural landscape and regional development, the "bottom-up" regional development approach will be explained first. In contrast to the traditional "topdown" approach, which aims to promote equality among regions by redistributing economic activity to problem areas, the bottomup regional development model is based on supporting mainly indigenous firms in order to improve competitiveness (Pezzini, 2003; Halkier, 2006) and using local resources and characteristics while doing it (Begg, 1999; Gordon, 1999; Boschma, 2004; Halkier, 2006). In addition, it is viewed as the domain of a regional semi-autonomous body that is able to promote regions in terms of the competitiveness of indigenous firms and attraction of economic activity from outside the area (Danson, Halkier \& Damborg, 1998, p. 18-21). However, with the emphasis on the importance of concepts such as industrial districts, learning regions and competitiveness goes beyond the boundaries of individual firms. Non-economic factors such as cognitive, social, cultural and institutional factors are spatially bounded, shaped and reproduced in regional development (Boschma, 2004, p. 1002). The main concepts such as innovation, human resources, social resources, network relations (Eraydın, 2008, p. 8) and local dynamics shaping the economic growth of the region such as knowledge, labour flows and institutional structures (e.g. Lovering 1999; Aminy, 2002; MacKinnon et al., 2002, Coe et al., 2004) are emphasised. In parallel with these developments, models of destination competitiveness have been developed in the field of tourism (Crouch \& Ritchie, 1995; Dwyer \& Kim, 2003). These developments are reflected in some international documents in the field of cultural heritage and projects therein.

Some international documents (i.e. Paris Declaration, 2011; Namur Declaration, 2015) emphasize the link between cultural heritage and development. While heritage is linked with sustainable development in the Namur Declaration, one of the sub-themes is the relationship between heritage and regional development in the Paris Declaration. In the Namur Declaration (2015), the main two indicators can be inferred: (1) contributions of cultural heritage to landscape quality and to developing public spaces; and (2) improvement of the cultural heritage management capacity of the public sector. These indicators are related with the physical condition of the cultural landscape and the heritage management capacity of the public. The Paris Declaration emphasises the link between heritage conservation and regional development in the context of urban development, towns, rural villages and local economy and preservation of space. The criteria that can be created are as follows: (a) preserving historic districts and encouraging their restoration and regeneration; (b) working on regeneration; (c) promoting balanced planning and 
development; (d) recreating multifunctional, landscaped urban neighbourhoods; (e) fostering socio-economic regeneration and reusing built heritage in towns and rural villages; (f) providing employment for local communities through the maintenance of traditional agricultural and craft activities and preserving skills and expertise; (g) developing new sources of energy production through maintaining and bringing back into use local, sustainable, traditional energy production techniques; (h) protecting geological and archaeological heritage, groundwater and ecosystems; (i) promoting alternative modes of transport through maintaining regional and local communication networks such as railways and roads; and $(\mathrm{j})$ respecting historic landscape and traditional settlement patterns through preserving rural heritage and ensuring its appropriate reuse (ICOMOS, 2011).

In parallel with these theoretical developments, some projects (in England, Russia, Germany, New South Wales, England and Turkey) were implemented in different parts of the world. Here, the link between cultural heritage and regional development will be summarised with five examples: Stratford-upon-Avon (England), Weimar (Germany), Yasnaya Polyana (Russia), Southeast Anatolia (Turkey) and KosovoWest (Menteș, 2006; Abankina, 2013). Apart from the case of Kosovo West, which is explained in relation with a regional heritage plan, all other projects have been implemented. According to these cases, cultural heritage serves regional development through varieties of aspects such as a growth in tourism, increase in private investment, and increase in cultural infrastructure and changes in social structures. These aspects can be defined as main criteria for understanding the effects of the preservation of cultural landscape in regional developments. In particular, growing cultural tourism creates growth in businesses, especially in the service sector, and new employment opportunities, as shown in the cases of Stratford-upon-Avon, Weimar, Southeast Anatolia and Yasnaya Polyana (Abankina, 2013). In parallel with increases in cultural infrastructure investments, new institutions developing as an international centre were established in Weimar, Stratfordupon-Avon and Yasnaya Polyana (Abankina, 2013). Changes in real estate costs, due to tourism and new residents moving into the area, generally result in changes in the social structure. In the case of Stratford-upon-Avon, what is explained that the social structure of the city's population changed, due to high real-estate costs; specifically, middle- and high-income groups moved in (Abankina, 2013). According to the regional heritage plan of Kosovo West, cultural heritage can contribute to different aspects of regional development, such as building capacity among stakeholders to raise local/regional awareness of heritage, ensuring cooperation and a guarantee of a certain level of coordination and consistency of approach with relevant partners, ensuring the inclusion and participation of all communities, developing proper management policies, programmes and plans, maintaining on-going inventory preparation, monitoring the implementation of conservation projects, increasing cooperation and coordination between institutions, civil society and local 
authorities and so on (CE, 2015). For Turkey, some criteria can be identified through cases such as the South-eastern Anatolia Project (Menteș, 2006) and the research on tourism in Izmir/TR31 Region (Günlü, Pirnar \& Yağcl, 2009/ Figure 1). In the case of the South-eastern Anatolia Project, the development of cultural tourism (Menteș, 2006) can be defined as a main criterion. In the context of the research on the impacts of cultural heritage on regional development, some problems and obstacles for understanding why regional development cannot be achieved are explained, such as the lack of policy and a systematic process at the "regional İzmir (TR31 NUT2) level" and lack of cooperation between the governmental bodies and the private sector (Günlü, Pirnar and Yağcl, 2009).

In that respect, some criteria will be defined in relation to these examples. However, the contribution of a cultural landscape on regional development goes beyond the limits of tourism. Preservation and/or archaeology are also effective ways of ensuring the contribution of the cultural landscape to regional development. In this context, key criteria for analysing the roles of the cultural landscape for regional development will be defined below.

Figure 1. The location of TR31 Region and other regions in NUT 2 Level (Redrawn from the figure of Republic of Turkey Ministry of Development, 2013)

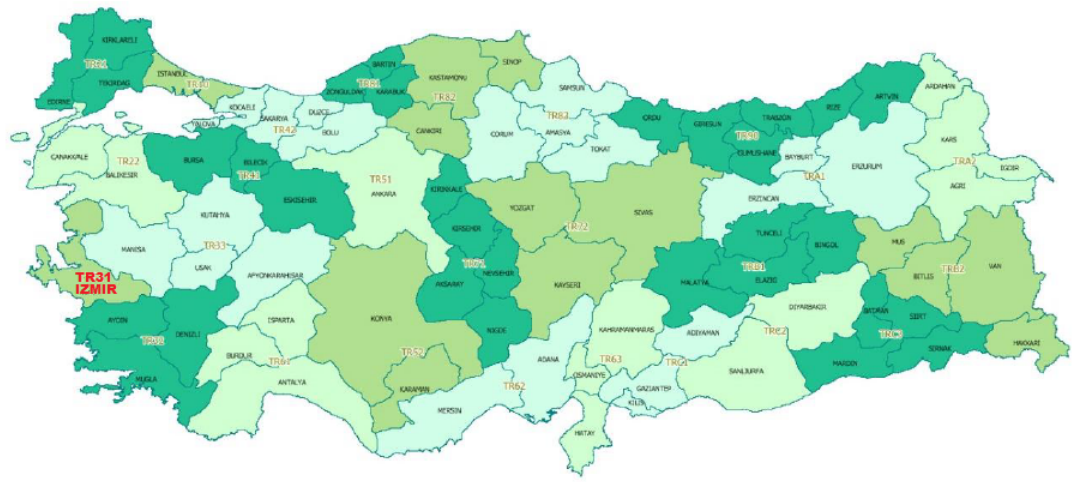

\section{A LOOKING IN CASE OF EPHESUS ACCORDING TO DEFINING CRITERIA}

The cultural landscape has potential to contribute to regional development in terms of both economic and socio-cultural aspects. Some cultural landscapes are characterised by the visual incorporation of the geography, whether rural or urban, such as the Pergamon and its cultural landscape, and the Diyarbakır Fortress and Hevsel Gardens by man' (UNESCO, 2014). This paper focus on Ephesus and its cultural landscape created through the superimposition of settlements in different periods and geography that can be traced from the 7 th millennium BC. Ephesus and its cultural landscape is formed by several sites including the Çukurici Mound; the Temple of Artemis, one of the Seven Wonders of the Ancient World; the monumental Hellenistic city wall and layout; cultural traditions of the Roman imperial period within the site of Ephesus; the Church of St. John,; the 
remains of the Turkish city from the $14^{\text {th }} / 15^{\text {th }}$ century; and the House of Virgin Mary. The area has an outstanding universal value due to the diversity of superimposition of geography and human settlements starting from the Neolithic age at Cukurici Mound up to the Middle Ages and beyond. Today, remains of urbanisation, architecture and religious history from the Prehistoric, Archaic, Hellenistic, Roman, Byzantine, Seljuk, Aydınogulları, Ottoman and modern period are located sometimes side by side, sometimes on top of each other. The physical, social and cultural traces of all the layers from Cukurici Mound to today's Selçuk co-exist in this area. In this context, it is necessary to give brief information about Selçuk.

Selçuk is located near international arrival points: the Adnan Menderes Airport (İzmir), Kuşadası Harbour and İzmir Harbour (Figure 2). Selçuk, as one of the stations on the the first railway in Anatolia dated back to $19^{\text {th }}$ century and as an old harbour on the Aegean Sea, presents significant potential for experiencing different modes of transport. Selçuk is heavily dependent on agricultural production. Since the 1980s; tourism has become a significant sector in Selçuk. It is ranked $75^{\text {th }}$ on the list showing the level of development in districts (State Planning Organisation, 2004) among 872 districts in Turkey. The 2009 census showed that 34,479 people live in. According to IZKA, the regional development agency of TR31 Region corresponding to the borders of the city of Izmir (1), Selçuk has high potential in terms of agriculture and tourism.

In this context, it is obvious that understanding the contributions of cultural landscape through examining key criteria is not a unique methodology. Many variables and criteria can be defined to facilitate an understanding of the extent and content of these contributions. As explained above, cultural landscapes have great potential for contributing to regional development in terms of economic and socio-cultural aspects. While economic contributions are assessed through indicators such as the creation of jobs and income, employment opportunities and financial flow, understanding the impacts of the cultural landscape on a region's socio-cultural development is a complex issue.

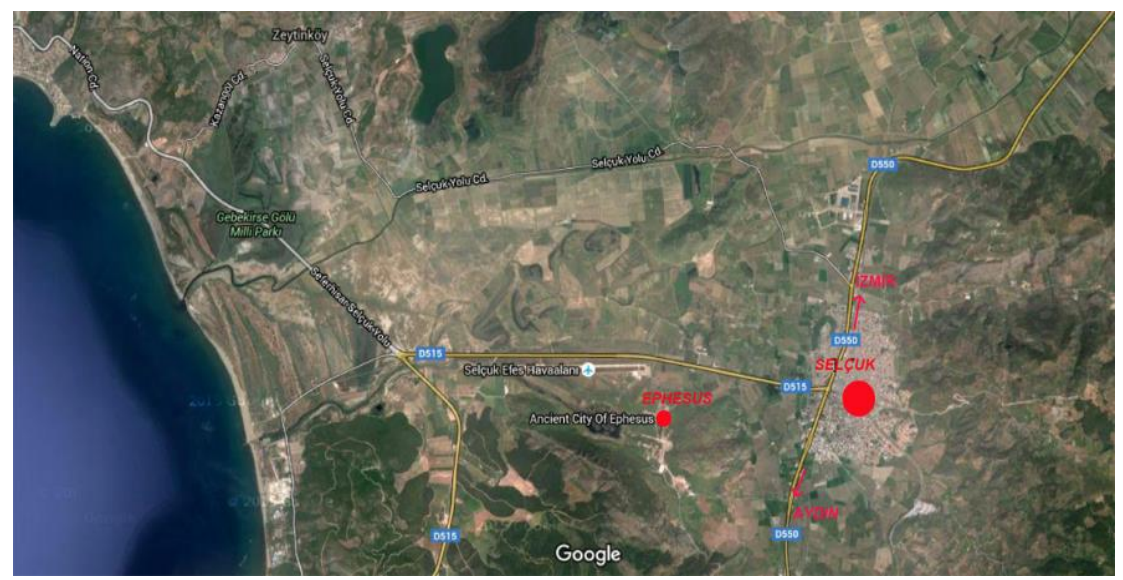

Figure 2. The location of Ephesus and Selçuk. (Source: Redrawn from Google map). 
On the one hand, currently, heritage plans developed at the regional level are generally based on a participatory process that encourages local actors to play an important role in maintaining and planning heritage (UNESCO, 2012, articles 39; 40) such as in cases of Kosovo West (European Council, 2012) and OkanaganSimilkameen (Denise Cook Design, 2015). On the other hand, currently, a regional heritage plan is not a valid tool for the preservation and development of cultural heritage in Turkey. Therefore, the social dimension of regional development will be analysed and evaluated taking into account the process of site management plan preparation, which is among the best tools for understanding participants' opinions at local and regional levels. The process of preparation of a management plan, which was introduced for the first time through Law 5226 (2004) and incorporated into Law 2863 (1983), and the Regulations concerning the Principles and Essentials Relating to the Monumental Masterpieces Council (2005), indicates good opportunities for the development of network relations and collaboration at the local and regional level. Especially, meetings that have to be organised throughout the preparation of the management plan can contribute to the development of network relations and collaboration. The following consists of three parts: (1) defining key criteria, (2) exploring the usefulness of these criteria through the case of Ephesus and its cultural landscape, and (3) evaluation.

These criteria can be classified according to a framework implying a three-fold classification as given in Table 1. Firstly, improvements in the physical quality of the cultural landscape are among the significant dimensions. The criteria relate to those physical qualities that are direct results of excavation, conservation and presentation activities (only one indicator is defined here), the installation of new infrastructures, and others. Secondly, the criteria of economic dimension (only five indicators are defined here) illustrate the economic gains achieved through archaeological excavations, researches, preservation activities, tourism and exogenous investments. Thirdly, the criteria of sociocultural dimension (only three indicators are defined here) relate to those social issues and situations. It is claimed that these indicators are useful to analyse the contribution of a cultural landscape, as a particular sub-region, to the regional development. For understanding some aspects of contributions of the cultural landscape to regional development, the actors who participated in the process of developing a management plan were interviewed. Of seventeen actors (2), nine were interviewed in April and May 2014 and the other eight were interviewed in July 2014. The following section highlights key indicators that illustrate the contributions of cultural landscape to regional development. 
Examinig the Role of Cultural Landscape in Regional Development:

Defining Criteria and Looking at Ephesus

Table 1. Criteria for understanding the contributions of cultural landscape to regional development

\begin{tabular}{|c|c|c|c|}
\hline Criteria & $\begin{array}{l}\text { Improvements in the } \\
\text { Physical Quality of } \\
\text { Cultural Landscape }\end{array}$ & $\begin{array}{c}\text { Economic } \\
\text { Dimension }\end{array}$ & $\begin{array}{l}\text { Socio-cultural } \\
\text { Dimension }\end{array}$ \\
\hline 1 & $\begin{array}{l}\text { Improving appearance } \\
\text { of cultural landscape } \\
\text { through excavation and } \\
\text { preservation activities }\end{array}$ & $\begin{array}{c}\text { Increasing } \\
\text { number of } \\
\text { visitors }\end{array}$ & $\begin{array}{c}\text { Developing } \\
\text { network relations } \\
\text { and collaboration }\end{array}$ \\
\hline 2 & $\begin{array}{l}\text { Installing new cultural } \\
\text { infrastructures }\end{array}$ & $\begin{array}{l}\text { Generating } \\
\text { income }\end{array}$ & $\begin{array}{c}\text { Capacity building } \\
\text { for local } \\
\text { development }\end{array}$ \\
\hline 3 & Others & $\begin{array}{l}\text { High number of } \\
\text { businesses in } \\
\text { service sector }\end{array}$ & $\begin{array}{l}\text { Contributing local } \\
\text { planning policies }\end{array}$ \\
\hline 4 & & $\begin{array}{c}\text { Developing } \\
\text { entrepreneurship }\end{array}$ & Others \\
\hline 5 & & $\begin{array}{c}\text { Attracting } \\
\text { exogenous invest }\end{array}$ & \\
\hline 6 & & $\begin{array}{c}\text { Increasing } \\
\text { regional tourism } \\
\text { competitiveness }\end{array}$ & \\
\hline 7 & & Others & \\
\hline
\end{tabular}

\section{Improving appearances of the cultural landscape through excavation and preservation activities}

As stated in the Namur Declaration (2015), the contributions of cultural heritage to landscape quality and to developing public spaces are indicators of regional development. Here, improvements in the physical quality of the cultural landscape will be analyzed. Excavations, preservation and presentation activities starting from the end of the $20^{\text {th }}$ century in many sites in Turkey have produced many results, and some of these results can be seen clearly in the appearances of the cultural landscape. Especially in the context of cultural landscapes constituting archaeological sites, uncovered areas of a city and fragmented architectural elements covered through excavation can be transformed into standing structures. These types of changes make sites and the cultural landscape visible and understandable. However, there are discussions on authenticity and what is valued. What is valued now may not be valued in the future and what is valued by specialists may not be valued by local people and/or tourists. Even the 'document values' can not long survive without positive 'experiential values' (Jiven and Larkham, 2003, p. 79). Besides as stated by Jokilehto, for more people the 'character and appearance' can be more significant than authenticity of 
original materials (1999). But, in case of cultural landcapes including archaeological sites such as Ephesus, Basilica of St.John how should such preferences be taken into account before the physical intervention? As Jiven and Larkham (2003) point out, there is a need to develop more theoretically informed conceptions of authenticity, character and sense of place, which should be informed by the views of the people directly involved. On the other hand, the integration of sites through management and planning efforts can improve the quality of the cultural landscape. Moreover, cultural infrastructures, which are necessary for tourism, create attractive centers.

The archaeological works and preservation efforts at Ephesus, and its cultural landscape continuing since the 1890s, have greatly changed the appearances of the site and its cultural landscape. (Şimşek, 2009). The Temple of Artemis, the Church of St. John, Ephesus, the Ayasuluk Hill and the House of Virgin Mary, which were mostly underground, have become visible through excavations and preservation efforts. For instance, the appearance of the Curetes Street and the standing structures on the street such as the Hadrian Temple, the Terrace Houses and the Celsus Library, have become visible (Figure 3). Thus, the improved appearance and quality of the physical environment of the cultural landscape serve as a resource for tourism and regional development.

Figure 3. Changes in the appearance of the so-called Trajan Temple in Ephesus. 3a. The so-called Temple of Hadrian throughout excavation, 1956 (Miltner, 1959, 53-4). 3b. The proposal for the south façade of the authentic design of the so-called Temple of Hadrian (Miltner 1959, 277-8). 3c. The state of the so-called Hadrian Temple after re-erection (Simsek, 2008).
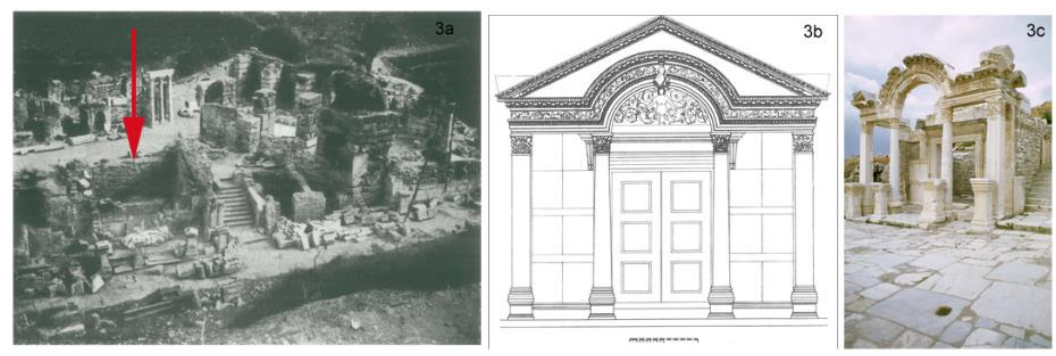

\section{Increase in the number of visitors and income generation}

As stated above, an increase in the number of visitors in a cultural landscape is another indicator of regional development. A high numbers of visitors have both positive and negative effects on the cultural landscape and the host community. On the one hand, there can be positive effects such as improvements in the quality of the physical environment, income generation, and growth of the service sector and creation of jobs for workers of all skill levels. However, a high number of visitors can also have negative effects such as erosion at sites and a decline in the perception of the meaning of physical characteristics of the cultural landscape. Although Rapaport points out that using a cultural landscape as the unit of analysis necessitates looking simultaneously at archaeological, traditional and contemporary landscapes, in this paper, the number of visitors at certain sites will be taken into account in order to understand the changes in visitor numbers. 
Many tourists visit Ephesus and its cultural landscape, and they generally enter via the ports of Kuşadası or İzmir. Currently, organised one-day tours always include Ephesus and one other neighbouring site (i.e. Selçuk Museum, the Church of St. John or the House of Virgin Mary). Visitors generally leave without visiting the town of Selçuk. This type of tour organisation brings independence from the local community, which is another obstacle to the improvement of social relations between the local community and visitors and for understanding vernacular and traditional lifestyle. In Ephesus, it can be seen that the number of visitors has risen rapidly over the last 30 years, from 300,000 (1982) to over 2 million (2012), and twice as many tourists are visiting Ephesus today than they did in 2000.

A large number of tourists (about 1.5 million in 2015) bring high income. In order to understand income generated through Ephesus and its cultural landscape, it is necessary to analyse the amount of income generated through entrance fees and car parking fees. In 2012, the entrance fees from Ephesus (US\$28 billion dollars) and income from car parking fees (US $\$ 4.3$ billion) were the two major sources of income in Izmir region. After these sources, the House of Virgin Mary, which brought in US $\$ 2$ billion, was the third one. It is followed by the Terrace Houses (US\$1.96 billion), the St. John Cathedral (with US $\$ 1.74$ billion) and the Ephesus Museum (US\$1.25 billion). The total income was almost US $\$ 37$ billion in 2012, which is 12 times greater than in 2003, as shown in Figure 4.

\section{Businesses growth in the service sector and supporting the development of entrepreneurs}

As explained, the cultural landscape can greatly influence the businesses, employment and development of entrepreneurs in a positive way. This effect is achieved not only through tourism, but also through archaeology and preservation. On the one hand, the effects of tourism have become one of the major subjects of research and policies in recent decades (Rypkema, 1999; Throsby, 1999; Avrami et al., 2000; Cernea, 2001; Greffe, 2004; Richards, 2005). It is estimated that 10,000 visitors create 1.15 direct jobs (persons employed in the museum itself), and every direct job creates 0.62 indirect jobs in the fields of interior architecture and conservation, and so on (Greffe, 2004). In addition, historic preservation creates more jobs and income than would be generated with the same amount spent on new construction (i.e. see Rypkema, 1999 and Throsby, 2012). In that respect, cultural landscape has great power to encourage small businesses such as restaurant, cafes, souvenir shops, other tourism-related businesses and entrepreneurship at the local and regional level. Here, the businesses will be categorised into three groups: (1) businesses serving tourists, (2) businesses in creative industries, and (3) businesses in science and preservation. 
Figure 4. Income from entrance fees and parking fees of Ephesus and its cultural landscape (Source: Selçuk Municipality Archive)
TOTAL INCOME (\$) PER YEAR

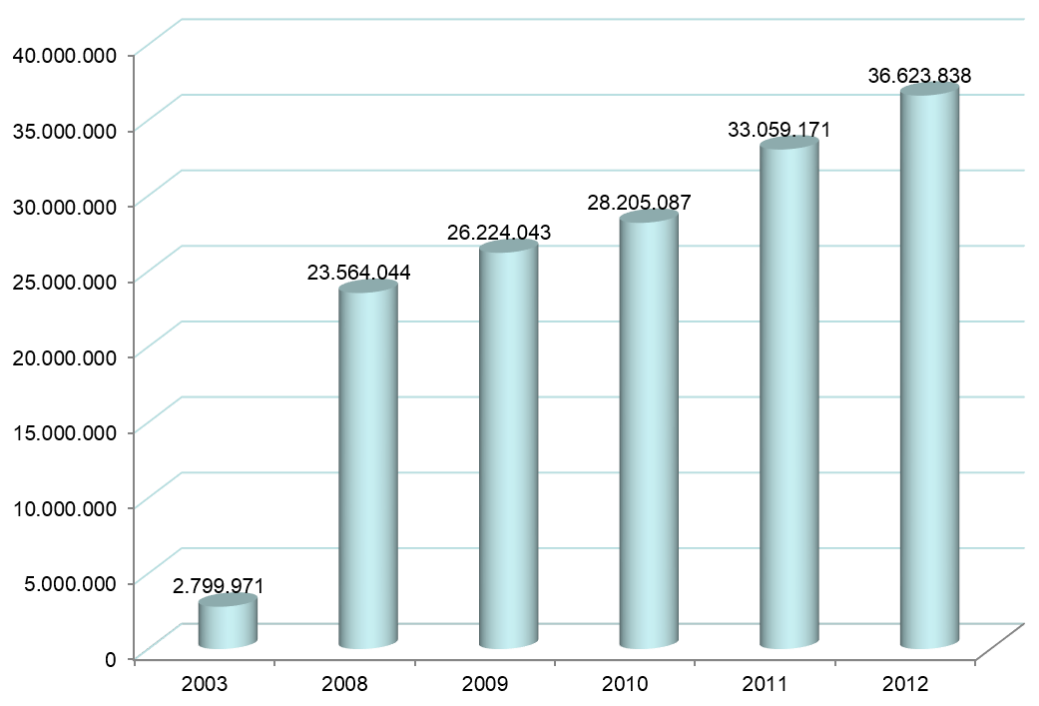

According to the data from the Chamber of Commerce, in 2014, among the total number of businesses, 30\% (190) businesses serve mainly tourists, in comparison to other businesses such as retailers and construction. As shown in Figure 5, the distribution of businesses in the tourism sector indicates that agricultural product sales $(27 \%, 48)$ and restaurants $(20 \%, 36)$ are the primary businesses. Souvenir sales $(14 \%, 24)$, carpet sales $(11 \%$, 20) and leather sales (11\%, 19) account for much smaller percentages. These are followed by hotels $(9 \%, 16)$ and jewellery sales $(8 \%, 15)$. In addition, the number of tourist guides serving in the region is above three hundred (3). As emphasised in the Paris Declaration (ICOMOS, 2011), the high number of agricultural product sales $(27 \%, 48)$ provides employment for the local community in Ephesus. However, it is possible to state that traditional agricultural and craft activities have not generally been maintained.

In the field of cultural industries, $48 \%$ of businesses serving mainly tourists (souvenir sales, carpet sales, leather sales and jewellery sales) directly relate with cultural industries, and there are 70 shops on the gates of Ephesus. In relation with Law 5226 'Incentives for Cultural Investments and Enterprises', the Ministry of Culture and Tourism leases a shop (including a coffee shop) in Ephesus to a particular firm in parallel with 47 other sites (Central Directorate of Revolving Funds, 2009). According to the Ministry of Culture and Tourism, there is an effort to raise the level of service standards at sites. However, leasing cultural sites to a particular firm is highly criticised due to the use of sites for personal and monetary benefits (Pulhan, 2009, p.147). In addition, shopkeepers on the gates of Ephesus have mentioned that the shop within the site creates unfair competition. Although the level of service standards and the quality of design and workmanship of the products sold in shops on the gates are low; leasing shops to a particular firm acts as an obstacle for developing local businesses, employment and entrepreneurship 
at the local and regional level. In addition, the construction of a mall by TURSAB is another obstacle for the development of small businesses. Interviews indicate that these kinds of investments from outside the region for the sake of evaluating tourism potentials discourage local people and have negative effects on building up competitiveness among local firms. Consequently, these practices fail to bring out the potentials of Ephesus and its cultural landscape for generating local businesses and entrepreneurship. Besides, as opposed to what is emphasised in the Paris Declaration, businesses do not generally contribute to preserving traditional skills and expertise at the local level.

In the areas of archaeology and preservation, a number of people work on digging and preserving edifices-such as the archaeological sites of Ephesus and the Ayasuluk Hill-and preserving monuments of different periods, such as Turkish Bath in Selçuk. In the case of Ephesus, Öztürk (2014) states that 141 researchers (including 30 researchers from Turkey) from 18 countries around the world worked for scientific research during the 2013 campaign. This indicates the importance of the archaeological site as a scientific resource and as a generator for research jobs. The number of workers is much higher if the ones working in Ayasuluk Hill and preservation projects are added. In that respect, Ephesus and its cultural landscape have high potential to contribute to the development of not only small businesses and entrepreneurships, but also businesses in science, preservation and construction.

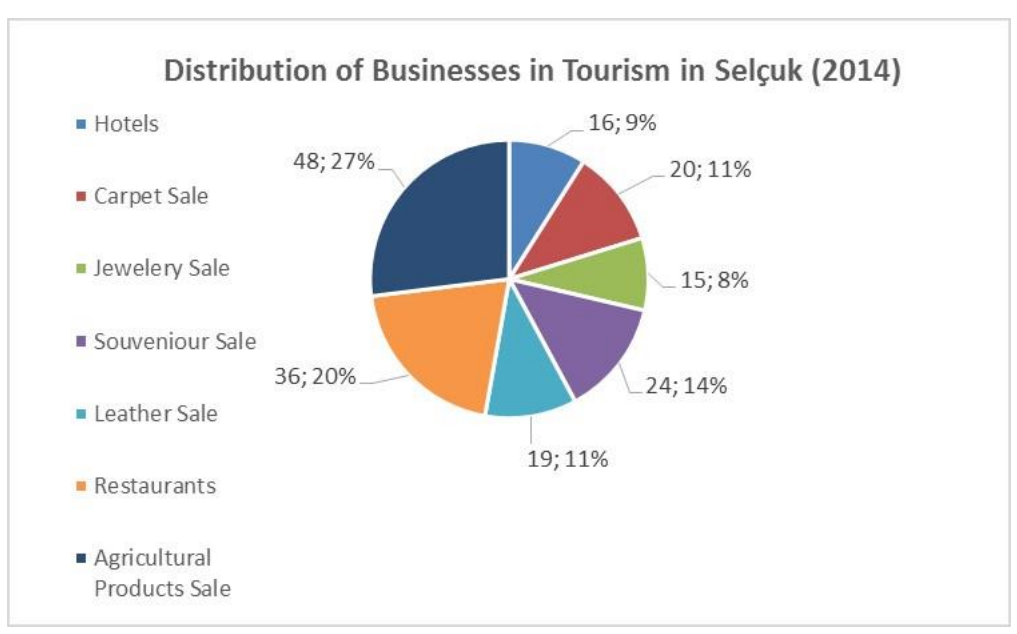

\section{Attracting exogenous investment}

The cultural landscape has great potential to attract the attention of peoples and institutions from all over the world. Attracting exogenous investment related with the potential of a region for attracting economic activity from outside the area (Danson, Halkier \& Damborg, 1998, p. 18-21) is another key criterion here, which is generally not mentioned in the heritage field. In the current literature, exogenous investment is generally examined in relation with tourism. However, archaeology, preservation and research may have great potential for attracting exogenous investment in the case of cultural landscape. For instance, several
Figure 5. Distribution of Businesses in Tourism in Selçuk, 2014. (Source: Selçuk Chamber of Commerce Archive). 
non-profit and profit institutions such as the National Endowment for the Humanities (US) and J.M. Kaplan Fund are evidence of the value and importance of cultural landscape for attracting exogenous investment.

This part focus on the case of Ephesus as a source of scientific research for attracting exogenous investment. A great amount of money has been spent since the early years of the excavation. In addition to the Austrian Archaeological Institute, which directs the excavation, thereby bringing in money to the project, several governmental and non-government institutions have been investing in the projects at Ephesus. For instance, in 2012, the total amount of money spent for Ephesus was 2,746,532,82 € as shown in Figure 6. The pie chart compares the level of financial support given by institutions from around the world (4). In addition, the preservation activities of the General Directory of the Pious Foundation and other archaeological projects are other sources for understanding the whole effects of exogenous investments in regional development. Therefore, cultural landscape has great potential for attracting foreign investment through archaeology, preservation and tourism.

Figure 6. Budget for Archaeological Research and Preservation Works at Ephesus, 2012 (Source: Austrian Archaeological Institute Archive)
Budget $(€)$ for Ephesus and its Distribution in 2012

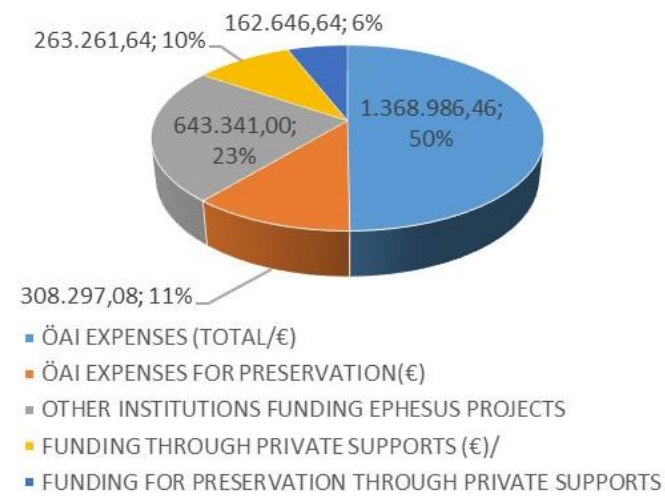

\section{Developing network relations and collaboration}

Heritage belongs to the whole community, and participation needs to take place at all levels. Besides, collaboration is a process throughout which the views of stakeholder groups are considered as legitimate as those of an expert (Bramwell and Sharman, 1999; Hall, 1999). In Turkey, site management plans that are generally based on a participatory process encourages local actors to play an important role in planning and management cultural landscape. The engagement of local communities with the cultural landscape is mentioned in relation with the introduction of the concepts 'management area' and 'site management' (article 3) through the Law of 'Conservation of Cultural and Natural Properties' (Law 5226, 2004) added to Law 2863 concerning the 'Protection of Cultural and Natural Heritage (1983). Further, establishing cooperation among partners is among the main purposes of a management plan, according to Article 5 of the Regulations Concerning the Principles and Essentials Relating to 
the Determining of Management Areas within the Foundation and Responsibilities of the Monumental Masterpieces (Şimşek, 2015). The partners are authoritative central, and local administrations and nongovernmental organisations specialised in this field, land owners, volunteers, institutions and the local public (2005). As stated, the emphasis on the participation of stakeholders from specific fields, especially preservation and planning, implies that a different type of collaboration is called for in the law. In this context, there are some problems with the definition in relation to the extent to which stakeholders are involved and which ones are excluded and with the meaning of the term 'collaboration', which is elusive.

According to interviews with the actors who participated in the preparation process of the management plan, the actors were mostly very satisfied with their involvement in the preparation process. The meeting was the first attempt of its type in Selçuk, welcoming diverse stakeholders from local and regional levels for the sake of preservation and management of the cultural landscape. However, some actors who worked on-site (the members of the Chamber of Tourist Guides of Aydin) and at the shops on the gates of Ephesus (the members of the Association of the Shopkeepers at Ephesus) stated that they did not have information and did not participate in the meetings. Among the stakeholders who participated in the meetings, some of them, such as the Chamber of Commerce in Selçuk and the Chamber of Tradesmen and Craftsmen, mentioned that they were not given any information on what a 'management plan' is before the first meeting. In addition, it was obvious that some respondents from authoritative local administrations participated in the meeting because they were required to do so.

The preparation process for the management plan can be divided into two stages in relation with the change in Selçuk's mayor due to the municipality elections on March 30, 2014. Most of the respondents agreed that, before the elections, the process did not influence their network relations or collaborations with other stakeholders. Some local organisations, such as the Austrian Archaeological Institute, the Chamber of Commerce in Selçuk, and the Chamber of Tradesmen and Craftsmen in Selçuk, stated that their views were not included in the management plan at first and that the management plan was not a joint decision among stakeholders. From the interviews, it is understood that the approach of the former mayor, including his low level of openness to participation, negatively influenced stakeholders' participation. In that respect, most of the respondents stated that the process did not offer them opportunities for developing network relations or collaboration among stakeholders.

After the elections, the new mayor of Selçuk took the approach of having a high level of interest and encouraging stakeholders to participate, and this influenced the process in a positive manner. Thus, the management plan preparation process activated stakeholders to engage directly with the cultural landscape. The production of a management plan has been highly significant in 
encouraging wide participation, especially at the local level. Some new network relations centring on heritage have emerged. Many meetings are needed to develop collaboration. Besides, it is indicated that the approach of the local leader is an important factor that influences the potential of the cultural landscape for establishing participation, network relations and collaboration. Consequently, there is great need to define what "collaboration" is in the context of management plan and support this process by other tools in order to contribute socio-cultural development at the local and regional level.

\section{Capacity building for local development}

The criterion 'capacity building for local development' needs to be articulated in relation with both 'capacity building' and 'local development'. The concept of 'capacity building' has been explained in relation with the capacity of people and institutions for playing an effective role in settlement planning and management (e.g. UN Rio Declaration, 1992; UNCED, 1996; UN, 1996). According to the OECD (2005), some effects of culture on local development are (1) to enhance synergy between players at the local level and (2) providing leverage for the creation of products. In the context of the programmes of regional development agencies in Turkey, the projects based on capacity building relate to diverse issues such as the development capacity of institutions and persons, economic and social coherence, innovation and entrepreneurship, and factory production quantities. Below, the role of cultural landscape in capacity building is examined in relation with these three aspects.

Improving the capability of people and capacity of institutions: Cultural landscape has the capacity to improve people's capabilities such as for doing research or performing jobs related to preservation and tourism. Moreover, cultural landscape can contribute by activating resources for the foundation of educational institutions at the local level. Thus, cultural landscape has the potential to activate local or exogenous resources for the foundation of some institutions and to improve the institutional capacity of the region and people's capability to do specific jobs.

Enhancing abilities, relationships and values that will enable organisations and institutions to improve their performance: Cultural landscape has great potential for enhancing abilities, relationships and values that will enable organisations and institutions to improve their performance at local and regional level. As explained above, the values of the cultural landscape for creative industries lead companies to improve their performance in this sector.

Enhancing people's and organisations' willingness to play new development roles: Cultural landscape has the potential to activate people for enhancing people's and organisations' willingness to play new development roles in the fields of preservation, cultural tourism and creative industries. Especially, the tourism potentials of cultural landscape lead people and organisations to play new development roles. Further, a 
management plan has the potential to contribute to the willingness of people and organisations to play new development roles. For facilitating people's and organisations' willingness to play new development roles, there is a great need for encouraging participation in the management process.

Ephesus and its cultural landscape pose both advantages and problems in relation with capacity building. On the one hand, they have great potential for building capacity by improving people's capabilities. For instance, the ceramic research on the pottery from the Hellenistic period to the Ottoman period-in which researchers from the University of Zurich, University of Salzburg, University of Sitkı Koçman and Austrian Archaeological Institute collaborate-indicates the potential for creating a scientific research environment at the global level. In addition, the 141 researchers (including 30 researchers from Turkey), who come from 18 countries across the world, show the significance of Ephesus for building capacity by improving people's research and vocational capabilities. On the other hand, this contributes to the generation of jobs in the tourism sector by activating investment in the education sector, such as the tourism vocational high school (Selçuk IMKB Otelcilik ve Turizm Meslek Lisesi, 2006). However, the people whose capabilities and skills were improved, cannot generally be actors in tourism implications and development at the local level. Therefore, there is a need for enabling an environment in which people can interact easily. The high tourism potential of Ephesus and its cultural landscape are also a good indicator of its role for building capacity. However, some practices, such as establishing a shop within Ephesus and TURSAB's construction of a new mall, discourage local people's and organisations' willingness to improve their performance. The construction of the mall was highly criticised by local people for failing to limit local shopkeepers' performances. Thus, there is a need to take into account the voices of local people and capacities of local companies before implementing certain practices at the local or regional level. As a result, encouraging stakeholders to participate and collaborate throughout the preparation of the management plan will have positive effects on enhancing people's willingness to play new development roles.

\section{Contributing to local planning policies}

Generally, management tools, especially management and planning, are viewed as an essential part of providing effective protection for a cultural landscape. The importance of developing an integrated approach to planning and management is highly stressed (UNESCO, 2012, article 112). In contrast to traditional planning approaches (top-down planning policy), the integration of planning and management adds a new participatory process and bottom-up planning policies. In Turkey, the local governments, especially local municipalities, were designated as responsible bodies for the preparation of management plans (2004, article 2). In that respect, the cultural landscape within the borders of a municipality has the potential to contribute to the planning studies of local governments at a theoretical level. A 
management plan has positive effects on the planning approaches of local municipalities. Thus, a new spatial unit and a new planning approach have been added to the practices of local municipalities beyond traditional physical planning.

In the Ephesus case, the respondents were also asked whether a management plan could positive effects on the development of local planning studies or not. It is surprising that the respondents usually agreed that a management plan has great potential for contributing to the planning policies of the municipality and changing their views on planning. Further, they were generally satisfied with their inclusion within this kind of process and with the opportunity to express their opinions. However, the exclusion of their opinions and views before municipality elections indicates that their efforts to participate in the management plan were insufficient. On the other hand, the new mayor's high level of openness to participation influenced the stakeholders' opinions. The findings show that the management plan has great potential to contribute to the development of local planning studies. In that respect, management plans have high potentials for expanding municipalities' planning approach beyond traditional physical planning.

\section{CONCLUDING THOUGHTS}

Cultural landscape has the potential to contribute to the broader social, cultural and economic goals of regional development through research/archaeology, preservation, tourism and creative industries. Ephesus and its cultural landscape demonstrate high contributions to local and regional development independent from the implementation of bottom-up regional policies and the regional heritage plan. It is necessary to repeat that the aim of this paper has been to clarify the possible contributions of cultural landscape to regional development. The data are mainly gathered from the Austrian Archaeological Research team. The data from other sites within the cultural landscape, such as Ayasuluk Hill and the Museum, show the exact contributions of cultural landscape in regional development. The criteria explained above can be developed and new ones can be added for developing a better framework for understanding how cultural landscape can contribute to regional development. Each criterion can be explained and discussed in a separate paper. New criteria can contribute to broad understanding of the contributions of cultural landscapes in regional development.

This paper has argued the necessity of considering the contribution of cultural landscape in order to conceptualise the ways in which communities can more effectively benefit from their cultural heritage for regional development purposes. This case indicates that cultural landscape has great potential to contribute to the economic development of a region. At the same time, it has potential to contribute to local community needs such as capacity building, development of network relations and collaboration and development in local planning studies. The case 
indicates that, although necessary legal instruments have been created for ensuring the participation of particular stakeholders in the management of a cultural landscape, the traditional topdown approach, as a dominant approach in Turkey, generally seems to act as a barrier to the inclusion of some stakeholders' views and voices. The key actor in regulating and managing the process of preparation of a management plan, has to develop an appropriate approach and avoid excluding the views of other stakeholders. The government's practices regarding the cultural landscape should take into account the importance of community for both cultural landscape preservation and regional development. There is a great need to expand the stakeholder groups, avoiding limitations with experts and interested groups, and to generate more active involvement in order to ensure collaboration and coordination in the community, as well as capacity building. Moreover, some practices that function as barriers to increasing competitiveness among local firms should be considered, and the voices of local peoples should be taken into account prior to implementation. Therefore, the great potential of cultural landscapes for 'providing employment for local communities through the maintenance of traditional agricultural and craft activities and preserving skills and expertise' (ICOMOS, 2011) should be supported by appropriate tools and applications. Government applications and different types of legal documents should be compatible and support each other for reaching the targets of both heritage management, planning and local and regional development.

The government, which plays an important role in supporting the community for better regional development, should support this process by creating necessary tools such as awareness raising programmes and regional heritage planning. For the sustainable preservation of cultural landscapes and better regional development, the management of cultural landscapes has to be planned at the regional level. Furthermore, heritage management planning needs to be implemented by a heritage institution, which acts as a kind of development agency, at the regional level. Management plans and site management-as tools proven to be effective at the sub-regional level in Turkey-need to be adapted at the regional level and placed in the centre in order to facilitate the needs of a better regional development. Besides, regional and local communication networks such as railways and old harbours can be included in the management and planning of cultural landscapes in order to better provide heritage contributions in the regional development.

\section{Acknowledgement}

This paper is based on post-doctoral research at the Austrian Archaeological Institute (Vienna) supported by the Higher Education Council. I would like to express my gratitude to Dr. Sabine Ladstätter (Director of the Austrian Archaeological Institute) for her supports and to the members of the Austrian Archaeological Research Institute for their kind supports during the research. 


\section{Notes:}

(1) According to the most up-to-date data (2001) of the Turkish Statistical Institute, Izmir is above Turkey's average of \$2,146 with its value of $\$ 3,215$ for gross domestic product (GDP) per capita values.

(2) Sabine Ladstätter (Director of the Ephesus Excavation), Cengiz Topal (Site Manager and Ephesus Museum Director), Yusuf Yavaş (archeologist, Selçuk Municipality), Yusuf Dereli (Director of the Assembly of the Selçuk Chamber of Commerce /shop owner at Ephesus Lower Gate), Özgür Aydoğan (Secretary of the Chamber of Tradesmen and Craftsmen) Tuba Gülamber (architect, Selçuk Municipality), Mustafa Büyükkoloncı (Director of the Excavation of Ayasuluk Hill and the Church of St. John), Özlem Vapur (Vice Director of the Ephesus Excavation Team), Vefa Ülgür (former mayor of Selçuk), Veysel Badem (Selçuk Kaymakamlı̆̆ı), Filiz Acargil (Secretary of the Chamber of Commerce), Hasan Topal (Director of the Chamber of Architects, Izmir Section), Mehmet Güngör (İzmir Regional Directory of Culture and Tourism), Aslı Korur Ergün (İzmir Regional Directory of Foundations), Levent Gürçavdı ve Ozan Sayın (Director and Vice Director of the Chamber of Tourist Guides of Aydin), Halil Düztaş (Chamber of Civil Engineers Selçuk Office) and Demet Yanbolu (Architect). I would like to thank to the respondents for their time and interest during the interviews.

(3) This information is given by Levent Gürçavdı ve Ozan Sayın (Director and Vice Director of the Chamber of Tourist Guides of Aydin).

(4) According to the pie chart, $61 \%$ of the total budget was brought by the Austrian Archaeological Institute, and of that amount, $11 \%$ was spent on preservation. In addition, $23 \%$ of the total budget was from public institutions such as the Austrian Science Fund, European Union and Austrian Academy of Sciences, Vienna University; several museums (e.g. Kunsthistorisches Museum); and other Austrian and international universities. Thirteen percent came from private institutions such as The Society of the Friends of Ephesos (Gesellschaft der Freunde von Ephesos, Austria), Ephesos Foundation (Turkey), American Foundation of Ephesus (USA), J.M. Kaplan Foundation (USA) and Borusan (TR).

\section{REFERENCES}

Abankina, T. (2013). Regional development models using cultural heritage resources. International Journal of Culture, Tourism and Hospitality Research, 7 (1), 3-10. Retrieved from.https://www.hse.ru/pubs/share/direct/document /98177196.

Aminy, A. (2002). Spatialities of globalization. Environment and Planning A, (34), 385/99. Retrieved from http://epn.sage pub.com/content/34/3/385.full.pdf+html.

Antrop, M. (2005). Why landscapes of the past are important for the future? Landscape and Urban Planning, 70. Retrieved from www.sciencedirect.com.

Austrian Archaeological Institute. (2014). Vienna: Austria.

Begg, I. (1999). Cities and competitiveness. Urban Studies, 36, 795-809. doi:10.1080/0042098993222.

Boschma, R. A. (2004). Competitiveness of regions from an evolutionary perspective. Regional Studies, 38(9), 10011014. doi:10.1080/0034340042000292601. 
Bramwell, B. \& Sharman, A. (1999). Collaboration in local tourism policymaking. Annals of Tourism Research, 26, 392-415. Retrieved from http://ac.els-cdn.com.

CE. (2000). European landscape convention. Retrieved from http://www.heritagecouncil.ie/

fileadmin/user_upload/Publications/Landscape/Europe an_Landscape.pdf.

CE. (2015). Namur declaration, The ministers of the states parties to the European cultural convention meeting in Namur on 2324April2015.Retrievedfrom https://www.coe.int/t/dg 4/cultureheritage/heritage/6thConfCultural.Heritage/ $\mathrm{Na}$ mur-Declar_en.pdf.

Central Directorate of Revolving Funds. (2009). Muze ve örenyerleri girislerine iliskin sikca sorulan sorular. Retrieved February 18, 2014, from http://dosim.kulturturizm.gov.tr/TR,51927/muze-veorenyerleri-girislerine-iliskin-sikca-sorulan-s-.html.

Cernea, M. (2001). Cultural heritage and development: A framework for action in the Middle East and North Africa. Retrieved from http://documents.worldbank.org/curate d/en/406981468278943948/pdf/225590REPLACEM1 ccession0A2003100110.pdf.

Coe, N.M., Hess, M., Yeung, H.W., Dicken, P. \& Henderson, J. (2004). 'Globalizing' Regional Development: A Global Production Networks Perspective. Transactions of the Institute of British Geographers, 29 (4), 468-484. doi: 10.1111/j.0020-2754.2004.00142.x.

Crouch, G. \& Ritchie, J.B.R. (1995). Destination competitiveness and the role of the tourism enterprise. In Proceedings of the Fourth Annual Business Congress, Istanbul, Turkey (43-8).

Danson, M., Halkier, H. \& Damborg, C. (1998). Regional development agencies in Europe: An Introduction and framework for analysis. In H. Halkier, M. Danson \& C. Damborg (Eds.), Regional Development Agencies in Europe (13-25). London: Jessica Kingsley Publishers.

Denise Cook Design. (2015). Regional heritage strategic plan for the regional district of Okanagan-Similkameen. Retrieved October.10,2015,.from https://www.rdos.bc.ca/departm ents/development-services/planning/projects/ heritagesites/regional-heritage-strategic-plan.

Dwyer, L. \& Kim, C. (2003). Destination competitiveness: Determinants and indicators. Current Issues in Tourism, 6(5),369/414 Retrieved from http://www.tandfonline.co $\mathrm{m} / \mathrm{doi} / \mathrm{pdf} / 10.1080 / 13683500308667962$.

Enright, M. J. \& Newton, J. (2005). Determinants of tourism destination competitiveness in Asia Pacific: Comprehensiveness and universality. Journal of Travel Research, 43(4), 339-350.

Eraydın, A. (2008). Politikalardan süreç tasarımına: Yeni bölgesel politikalar ve yönetişim modelleri. In 2. Bölgesel kalkınma sempozyumu bildiri kitabı, Çok düzlemli yönetişim bildiri kitabı, Ege Üniversitesi, İzmir (pp.5-24). 
Europe Nostra. (2006). The Malta declaration on cultural tourism: Its encouragement and control. Retrieved from http://www.europanostra.org/UPLOADS/FILS/Malta_de claration_Cultural_Tourism.pdf.

Gordon, I. R. (1999). Internationalisation and urban competition. Urban.Studies.36, 1001 16. doi:10.1080/0042098993321.

Greffe, X. (2004). Is heritage an asset or a liability? Journal of Cultural Heritage,.5, 301.9. doi:10.1016/j.culher.2004.05. 001.

Günlü, E., Yağcl, K. \& Pirnar, İ. (2009). Preserving cultural heritage and possible impacts on regional development, Case of Izmir. International Journal of Emerging and Transition Economies, 2 (2) 213-229. Retrieved from https://www.researchgate.net/publication/270337742_ Preserving_Cultural_Heritage_And_Possible_Impacts_On_ Regional_Development_Case_Of_Izmir.

Hall, C. (1999). Rethinking collaboration and partnership: A public policy perspective. Journal of Sustainable Tourism, 7 (3\&4), 274-289. doi:10.1080/09669589908667340.

Halkier, H. (2006). Regional development agencies and multilevel governance: European perspectives. In Bölgesel Kalkınma ve Yönetişim Sempozyumu Bildiri Kitapçığı, (pp.3-17). Retrieved from http://www.tepav.org.tr/upload/files/13 21362529/2.Bolgesel_Kalkinma_ve_Yonetisim_Sempozyu mu_Bildiri_Kitabi.pdf.

ICOMOS. (1999). Cultural tourism charter. Retrieved from http:// www.icomos.org.

ICOMOS. (2011). The Paris declaration on heritage as a driver of development, adopted at Paris, UNESCO headquarters, on Thursday 1st December 2011. A Retrieved from http://www.icomos.org/Paris2011/GA2011_

Declaration_de_Paris_EN_20120109.pdf.

Izmir Development Agency. (2012). 2012 Yllı doğrudan faaliyet desteği. Retrieved from http://www.izka.org.tr/ destekler/onceki-donem-mali-destek-programlari/2012dogrudan-faaliyet-destegi.

Jiven, G. \& Larkham, P.J. (2003). Sense of Place, Authenticity and Character: A Commentary. Journal of Urban Design, 8 (1) 67-81.

Kozak, M. \& Rimmington, M. (1999). Measuring tourist destination competitiveness: Conceptual considerations and empirical findings. Hospitality Management, 18 (3), 273383. Retrieved from http://www.sciencedirect.com/scie nce/ article/pii/ S0278431999000341.

Lovering, J. (1999). Theory led by policy: The inadequacies of the "New Regionalism". International Journal of Urban and Regional Research, 23, 379-395. Retrieved from http://onlinelibrary.wiley.com/doi/10.1111/14682427.00202/epdf.

Jokilehto, J. (1999) A History of Architectural Conservation. Oxford: Butterworth.

Mackinnon, D., Cumbers, A. \& Chapman, K. (2002). Learning, innovation and regional development: A critical appraisal of recent debates. Progress in Human Geography, 26, 293- 
311. Retrieved from http://citeseerx.ist.psu.edu/viewdoc /download?doi=10.1.1.89.3449\&rep=rep1\&type=pdf.

McCarthy, J. (1994). Are sweet dreams made of this? Tourism in Bali and Eastern Indonesia. Northcote, Vic.: IRIP.

McKercher, B., Hoa, P. \& Du Cros, H. (2005). Relationship between tourism and cultural heritage management: Evidence from Hong Kong. Tourism Management, 26, (539-548). Retrieved from www.sciencedirect.com.

Menteş, G. (2006). Kültürel mirasın korunması ve turizmin geliştirilmesi için bir yönetişim modeli, Güneydoğu Anadolu örneği. Bölgesel Kalkınma ve Yönetişim Sempozyumu Bildiri Kitapçığı, (pp.319-337). Retrieved from http://www.tepav.org.tr/upload/files/1321362529 2.Bolgesel_Kalkinma_ve_Yonetisim_Sempozyumu_Bildiri_ Kitabi.pdf.

OECD. (2005). Culture and local development. Retrieved from http://www.oecd.org/leed-forum/publications/ Culture \%20and\%20Local\%20Development.pdf.

O'Keefe, T. (2007). Landscape and memory: Historiography, theory and methodology. In N. Moore \& Y.Whelan (Eds.), Heritage, Memory and the Politics of Identity, New perspectives of the Cultural Landscape (pp. 3-18). Retrieved from Ashgate e-Book.

Öztürk, F. Personal communication, April 4, 2014.

Pezzini, M. (2003). Cultivating Regional Development: Main Trends and Policy Challenges in OECD Regions. Retrieved from http://www.alternativasycapacidades.org/sites/default/ files/biblioteca_file/Pezzini\%20Mario.\%20Cultivating\% 20regional\%20development.pdf.

Pulhan, G. (2009). Cultural heritage reconsidered in the light of recent cultural policies. In S. Ada \& H.A. Ince (Eds.), Introduction to cultural policy in Turkey (pp. 137-158). Istanbul: Istanbul Bilgi University Press.

Regulations Concerning the Principles and Essentials Relating To The Determining of Management Areas Within The Foundation and Responsibilities of the Monumental Masterpieces Council, RGT 27.11.2005. 26006.

Richards, G. (2005). Cultural tourism in Europe. Retrieved from http://www.tramresearch.com/cultural_tourism_in_europe.PDF.

Rypkema, D. (1999) Culture, historic preservation and economic development in the 21st century. Paper presented at Leadership Conference on Conservancy and Development. Retrieved from http://www.columbia.edu/cu/china/DR PAP.html.

Şimşek, G. (2015). Arkeolojik varlıklarla ilgili yasal düzenlemeler. Aydın: Emre Dijital Ofset Matbaacılık.

Şimşek, G. (2009). Interventions on immovable archaeological heritage as a tool for new formation process. Unpublished doctoral dissertation, Middle East Technical University.

State Planning Organization. (2004). İlçelerin Sosyo-Ekonomik Gelişmişlik Sıralaması Araştırması. Retrieved from http://kirklareli.gov.tr/90planlama/90diger/dokuman/ 
dpt_ilcelerin_sosyo_ekonomik_gelismislik_siralamasi_ arastirmasi_2004.pdf.

Throsby, D. (2012). Investment in urban heritage, economic impacts of cultural heritage projects in FYR Macedonia and Georgia. Available from http://siteresources.worldbank.org/INTURBANDEVELO PMENT/ Resources/336387 1169585750379/UDS16_In vestment+in+Urban+Heritage.pdf.

Throsby, D. (1999). Cultural capital. Journal of Cultural Economics, 23, 3/12. Retrieved from http://culturalheritage.ceistorv ergata.it/virtual_library/Art.\%20 \%20Cultural\%20Capit al_D.\%20THROSBY.pdf.

UNESCO. (1992). Guidelines on the inscription of specific types of properties on The World Heritage List. Retrieved from http://whc.unesco.org/archive/opguide05-annex3en.pdf.

UNESCO. (2012). Operational guidelines for the implementation of the World Heritage Convention. Retrieved from http://whc.unesco.org/archive/opguide12-en.pdf.

UNESCO. (2014). Diyarbakır Fortress and Hevsel Gardens, Cultural Landscapes. Retrieved from http://whc.unesco.org/uploa ds/nominations/1488.pdf

Urry, J. (1990). The tourist gaze. London: SAGE publications.

Vos, W. \& Meeks, H. (1999). Trends in European cultural landscape development: Perspective for a sustainable development. Landscape and Planning, 46. Retrieved from www.sciencedirect.com.

\section{Resume}

Gökçe Şimşek received Bachelors in Architecture (1996) from Istanbul Technical University and M.Sc. in Conservation (2002) degree and PhD. in Architecture (2009) from METU-Middle East Technical University, Ankara, Turkey. Conducted a post-doctoral research at the Austrian Archaeological Institute in 2013-2014 on the impacts of archaeological sites on regional development. Her research interests focus on preservation of archaeological heritage, issues on the impacts of cultural heritage on regional development, gender issues in preservation of cultural heritage and preservation education. Since 2009, she has been a member of Department of History of Art, Adnan Menderes University in Turkey. 